FACTA UNIVERSITATIS

Series: Architecture and Civil Engineering Vol. 11, No 1, 2013, pp. 27 - 33

DOI: 10.2298/FUACE1301027C

\title{
STUDENT HOUSING UNIT IN A FLOOR AREA WITHOUT CORRIDORS *
}

UDC 711.4.01:72.012.6=111

\author{
Nikola Cekić ${ }^{\#}$, Miomir Vasov, Igor Bjelić \\ University of Niš, The Faculty of Civil Engineering and Architecture, Serbia \\ "ncekic@yahoo.com
}

\begin{abstract}
This paper treats the issues of position and urbarchitectonic-functional organization of a housing unit in a floor area without corridors in a student hostel. The authors advocate a new, more rational and functional concept in which the student room is not in direct contact with the corridor communication, but belongs to the housing unit, student apartment for 4-6 users. In a more rational organized volume, the living of the students is more comfortable and has a different character. The socialization conditions for the users are better, and the conditions for efficient studying more stable.
\end{abstract}

Key words: student housing unit, floor area, functional organization, organization concept, housing architecture.

\section{INTRODUCTION}

The increasing number of students in various education process in the world, especially those who are in the third age of life, imposed a need for an increased housing of the academics in student hostels, and rendered topical the issue of designing and construction of new buildings. For example, in Russia there was a competition ${ }^{1}$ for the best conceptual urbarchitectonic design of a student hostel. There was similar competition in Germany $^{2}$ aimed at obtaining as rationally organized volumes as possible, with the accent on the housing areas with functional housing units. Apart from that, we wish to make

\footnotetext{
Received January 25, 2013

* Acknowledgement: This paper is a part of the scientific-research project: "Construction of Student hostels in Serbia at the beginning of 21st century", approved by the Ministry of Science and technological development of the Government of the Republic of Serbia, in Belgrade, January 2011. Project manager, Prof. Ph D Nikola Cekić, Grad. Eng. of Arch. The Faculty of Civil Engineering and Architecture of the University of Nis. Project number: TR 36037.

${ }^{1}$ Competition for the best architectural project of the student dormitories. Second round. The Union of Architects of Russia Federal Fund for Housing Development (RHD Foundation), Moskva 25.11.2011. year. http://archi.ru/events/extra/event current.html?eid=5815\&fl=2\&sl=1

${ }^{2}$ Landeswettbewerb 2009/2010: Innovative Wohnformen für Studierende in gemischten Quartieren. http://www.mbv.nrw.de/Wohnen/Wettbewerbe1/LandeswettbewerbWohnungsbau/index.php
} 
topical the urbarchitectonic-designing solutions of the students produced in the studio of prof. arch. Mate Bajlon, at the Faculty of Architecture in Belgrade in 1970.

There are deficiencies of a characteristic housing floor area of student hostels dominated by the double-tract or triple-tract corridors, manifested in large surface area devoted to the corridors. For this reason, in this paper we are presenting six indicative solutions, of a sectional type, where the dominating communication in the buildings has a vertical character. We will present the volumes from the various countries of the world.

\section{EXPOSITION}

In this small research, we have focused our attention on the developmental dimension of student hostels, based on several indicative conceptual designs for architectonic organization of student hostels. Even though solutions belong to the concepts from the second half of the last century, it is our opinion that they have not been outdated, and that they deserve to be re-analyzed in innovative-rational terms. We observe the largest evolutional advancement in the necessary change of number of users in a student apartment and usability of the apartments. The room sizes, reaching the pathological threshold of 6 $\mathrm{m}^{2}$ should definitively be abandoned in the further designing as well as the manner of grouping of student apartments, where the structure of the group with more than six users begins to have a decisive effect on the lowering of comfort conditions and the living quality in a collective. The increase of the student apartment is also necessary for the computer "tools" which necessitated an increase of working area of no less than $1 \mathrm{~m}^{2}$.

The conceptual urbarchitectonic design for the floor layout of a student hostel from Russia $^{3}$ - Fig. 1., is of a standard character.

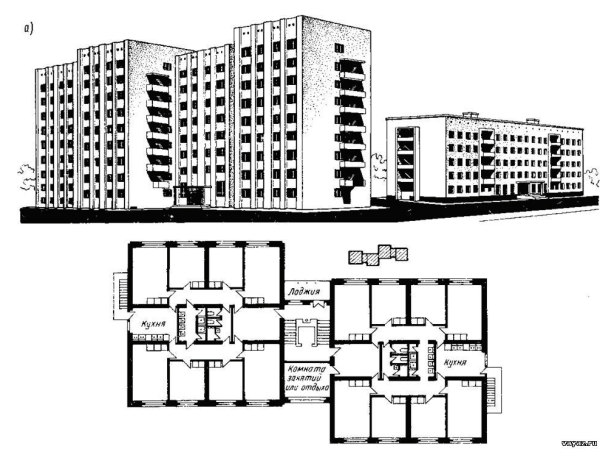

Fig. 1. Standard, planned sectional design of floor layout

It contains two housing units for 40 users. They are accessed from the staircase platforms at semi-levels. Each housing unit has two groups of users, 10 students each, accommodated in two double and two triple rooms, while the ante rooms, common kitchen and hygienic-sanitary fittings are located in the central part of the volume. The common

${ }^{3}$ OAO CNIIEP DWELLINGS, 127434, Moscow, Dmitrovskoye Highway 9, Pp. March 1965. year. www.ingil.ru, http://vayaz.ru/_nw/9/80430628.jpg 
rooms in the design are the rest room and the open area - loggia. The structural system of the structure comprises transverse and longitudinal bearing walls.

In case of the characteristic floor plan volume of the student hostel in Berlin ${ }^{4}$ - Fig. 2. , there are clearly distinguished four housing entities around a vertical communication core which houses the common rooms - kitchenette and storeroom.

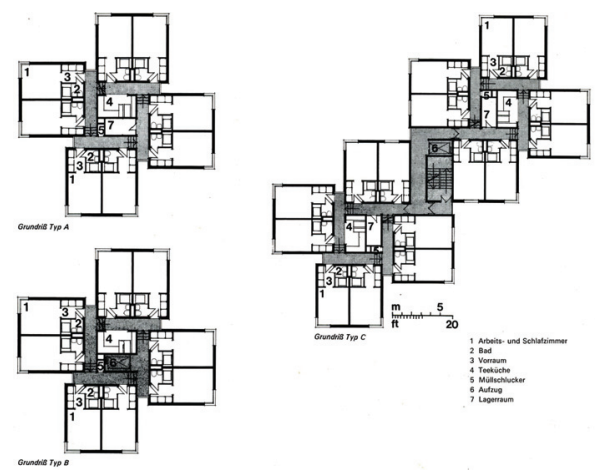

Fig. 2. Design of sectional layouts of floor areas of student hostels of the University of Berlin

The housing entities are approached from the platforms which are four steps off-level. The housing entity comprises two apartment units, for no more than four users, and each has its own hygienic-sanitary fittings. The rooms are double, and if necessary can be single. The position of a corner window is characteristic, with a working area in that zone. The floor volume is Conceived to be flexible, so that it can be repeated and linked into a row of buildings, 4-8 and more storeys high.

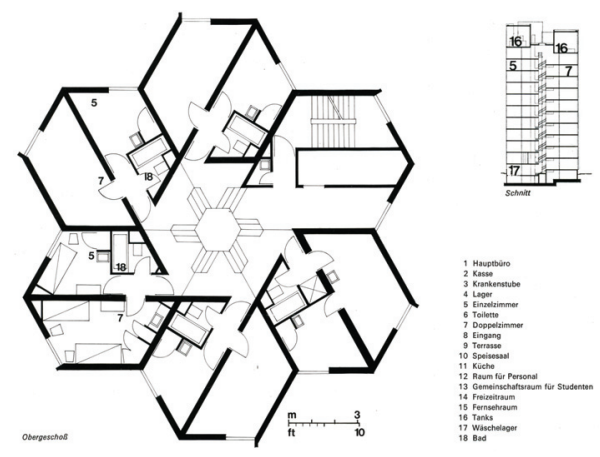

Fig. 3. Floor layout of the student hostel tower "Crystal Palace" in London

The tower of the student hostel "The Crystal Palace", in London ${ }^{5}$ - Fig. 3., has a very peculiarly designed layout of the a characteristic floor area volume using a hexagonal matrix, for 130 users. It contains 5 hexagonal volumes with housing apartment units with three beds.

${ }^{4}$ Design for the Free University of Berlin. Architects: Kraemer, Pfenning and Sieverts, Braunschweig, 1976 to 1978 "Bauwelt" 51/52/1959. 
Each has two rooms, a single and a double, of a trapezoid volume and its own hygienic-sanitary fittings. Due to the polygonal geometry of the room volume, there is problem in arranging the orthogonal equipment and furniture, so the functional area has not been fully and rationally used. They are accessed from the stairway platforms, which are four steps off-level. In the sixth, hexagonal field, there is a vertical staircase communication with lifts. The building structure is made of reinforced concrete.

In the compact structure of a characteristic housing floor plane of the student hostel in Princeton ${ }^{6}$ - Fig. 4., which has a square layout, with four clearly separated housing entities, the housing for 24 users is provided for.

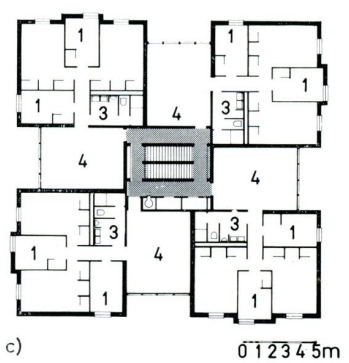

Fig. 4. Characteristic floor layout of a student hostel in Princeton

The housing unit is conceived with two single and two double rooms with the common hygienic-sanitary fittings and a large, common, pass-through living room in the entry zone. In the central part of the volume, there is a staircase with lifts. There is potential to multiply these structures on this location and to create a row of buildings.

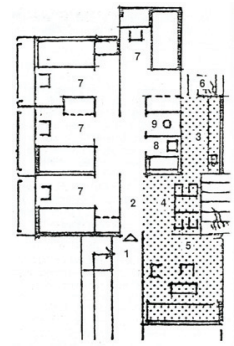

Fig. 5. A design proposition for the apartment layout for four users in the student hostel of Banja Luka

In the conceptual design of the architectonic design for the student hostel in Banja Luka, the student Milan Pavković ${ }^{7}$ - Fig. 5., suggested a very modern layout of an apartment for four

\footnotetext{
5 Student hostel "Crystal Palace", in London, 1964. Architects: L.C.C. (London Country Council) Hubert Bennett, London. http://tocs.ulb.tu-darmstadt.de/21684243.pdf

${ }^{6}$ Architect Hugh Stubbins and Partner; http://etcweb.princeton.edu/campusgiffiles/newquadicon.gif

${ }^{7}$ Destroyed in the earthquake of $27^{\text {th }}$ October 1969. At the Faculty of Architecture in Belgrade, a large number of conceptual designs were created as the aid to the city. The design of the student Milan Pavković from the Faculty of Architecture in Belgrade, in the school year of 1970/71.
} 
users, accommodated in single rooms in quiet zones, while the remaining functional areas are located in the entry zone of the apartment, with an open area.

The layout is flexible and permits functional remodeling. This design, even though it was created years ago, is still topical nowadays. It indicates the necessity of urb-architectonic and organizational and functional changes which should be conducted in student hostels and dwelling areas intended for academics. Living in single rooms is particularly important for necessary concentration and efficient intellectual a activities of the lodgers. This poses the key question about the sense of further existence of triple rooms in student hostels.

For the student hostel in Podgorica ${ }^{8}$ - Fig. 6., the designer provided a conceptual design with housing for nine ${ }^{9}$ and ten ${ }^{10}$ users, placed in five rooms, having surface area of $12.49 \mathrm{~m}^{2}$ and $7.84 \mathrm{~m}^{2}$ with loggias, common hygienic-sanitary fittings and a balcony.

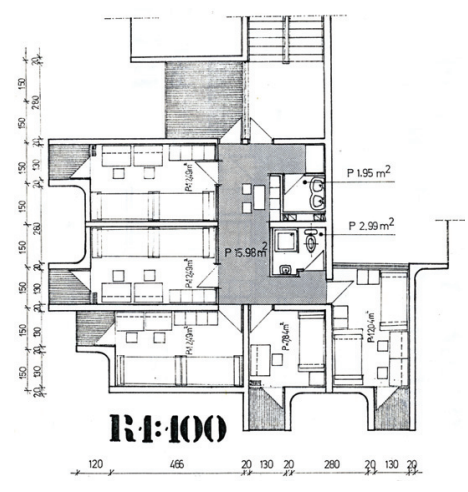

Fig. 6. Layout of the student apartment of the Student Hostel in Podgorica

There is no living room in the apartment, while the small dining room is located near the kitchenette in the ante-room. The structure of the building is made of reinforced concrete.

\section{CONCLUSION}

It is our opinion that the disposition of a student apartment with 4-6 users, which is directly connected to the vertical communication, therefore a sectional option of a characteristic floor plan in a building, yields a very rational, functional design, in which the users have the best living conditions. The structure of the student apartment which can be seen in realized urb-architectonic designs most often consists of double rooms, and some triple rooms, while the number of single rooms is the lowest. In our view, in the near future, the concept will have to change radically, so that the single rooms concept will prevail, within the minimum surface area of $8 \mathrm{~m}^{2}$. There will be no less than $80 \%$ of them, while the maximum share in the capacity would have the double rooms with $20 \%$. Triple rooms in the student hostels

\footnotetext{
${ }^{8}$ Student hostel - I and II pavilion in Podgorica. Designer: Milan Popović, graduate engineer of architecture. 1974-1978.

${ }^{9}$ Type A $-86.39 \mathrm{~m}^{2}$, Four double and one single room

${ }^{10}$ Type B - 90,59 $\mathrm{m}^{2}$, Five double rooms
} 
should be ruled out in the future as prominently dysfunctional and uncomfortable for academic lodging. The triple rooms, when reconstructing the existing buildings, should be rearranged to accommodate a reduced number of users. The reason for this view lies in the fact that a large number of students in the world, and especially those who study in the framework of the Bologna declaration, have the transitional character, and that they will not spend their total time of studies in only one academic environment.

The student housing unit in a volume without corridors and organized in sections, has several advantages over other urb-architectonic designs. We would like to point out the reduced length of the horizontal communication with a large number of vertical communication cores and the compactness of the building floors layouts, which contributes to a better thermal and acoustic insulation. Apart from that, the living and working comfort in hostels is enhanced. The coherence of housing groups and individuals is more expressed. It is very important to analyze in this the reduction of investment construction costs, as a large surface area of corridor space is reduced, that is, the concentration of student apartments in the zone of staircase verticals is increased.

\section{REFERENCES}

1. A. Phyllis, W. Mullins, "Ein Platz für Studenten", Bauverlag GmbH; Wiesbaden, 1975.

2. A. Bach, "Wohnheime", VEB Verlage für Bauwesen; Berlin, 1970.

3. Булева Д. Лилияана, Константинова Е. Анастасия, "Общчежития за студенти и ученици"; с. 7 - 35 ; "Техника", София, 1978.

4. M. Baylon, B. Milenković, B. Aleksić, M. Živković, "Studentski domovi - predlog normativa"; Zavod za ekonomiku domaćinstva SR Srbije; Beograd, 1977.

5. M. Baylon, "Stanovi za studente u Banja Luci", Rad studenata Arhitektonskog fakulteta u Beogradu u 1970/71. školskoj godini. UDK: 728.45. Dokumentacija za građevinarstvo i arhitekturu DGA-1237, sveska: 239, Beograd, 1972.

6. N Cekić, "Oblici studentskog stanovanja"; Specijalistički rad. Arhitektonski fakultet Univerziteta u Beogradu; Beograd, 1980.

7. N. Cekić, "Analiza i vrednovanje stambenih etaža studentskih domova u Jugoslaviji"; Doktorska disertacija, Građevinski fakultet Univerziteta u Nišu; Niš, 1989.

8. N. Cekić, M. Dačić, A. Jovanović, "Environmental Formation of Facades", časopis: "Facta Universitatis", Series: Architecture and Civil Engineering, Vol. 9, No 3, 2011, pp. 463 - 472, DOI: 10.2298 / FUACE1103463C, UDC 72.012.6:502/504=111

9. N. Cekić, O. Ilić, A. Jovanović, "Architectonic tendencies in Formation of charachteristic Floor Plans of Student Hostels". Faculty of Architecture at Varna free University "Chernorizets Hrabar" - The 5th International Scientific Conference "Architecture, Building - Modern Times". June 8-10, 2011. Varna, Bulgaria.

10. N. Cekić, O. Ilić, A. Jovanović, "Construction of Student Hostels at the begininng of $21^{\text {ST }}$ Century". International Balkans Conference on Challenges of Civil Engineering, EPOKA University, Tirana, Albania, BCCCE, ISBN 978-9928-4044-7-3, s. 111, 19-21 May 2011, Tirana.

11. N. Cekić, "Studentsko stanovanje"; Magistarski rad, Arhitektonski fakultet Univerziteta u Beogradu; Beograd, 1982. 


\section{STUDENTSKA STAMBENA JEDINICA U NEKORIDORNOM ETAŽNOM GABARITU}

\section{N. Cekić, M. Vasov, I. Bjelić}

U ovom radu otvaraju se pitanja položaja i urbarhitektonsko-funkcionalne organizacije stambene jedinice u nekoridornom etažnom gabaritu studentskog doma. Autori se zalažu za novi, racionalniji $i$ funkcionalniji koncept u kome studentska soba nije u direktnom kontaktu sa koridornom komunikacijom, već pripada stambenoj jedinici - studentskom stanu za 4-6 korisnika. U racionalnije organizovanom gabaritu stanovanje studenata je komfornije i sa drugačijim karakterom. Mogućnost za socijalizaciju korisnika je bolja a uslovi za efikasno studiranje stabilniji.

Ključne reči: studentska stambena jedinica, etažni gabarit, funkcionalna organizacija, koncept organizacije, stambena arhitektura. 